\title{
Implementation of Occupational Health and Safety in Sanitary Landfill work using Analytical Hierarchy Process Method
}

\author{
${ }^{1}$ Himalaya Bima Kenzo, Nunung Widyaningsih ${ }^{2}$ \& Bambang Purwoko Kusumo Bintoro ${ }^{3}$ \\ ${ }^{1-3}$ Department of Civil Engineering \\ Mercu Buana University, Jakarta, Indonesia
}

\begin{abstract}
Sanitary Landfill System is a waste management system that paid attention to environmental sanitation aspects. The process of spreading and compaction of waste in the landfill area and closing the waste cells is carried out every day. The increasing rate of population growth resulted in an increase in various activities and interests of people. Because of the increased work at the landfills, so, Work safety management is very needed In the implementation and constraints that will arise. The factors that cause the Implementation and Constraints in this waste processing consist of 2 criteria and 7 sub-criteria. This research used Analytical Hierarchy Process (AHP) to get the factors in the implementation and Constraints in carrying out work safety management. The assessment was carried out by 9 experts who have competence in the field of health and work safety, especially in the field of waste. The most dominant factor in the implementation of Occupational Health and Safety (OHS) with the sub-criteria for OHS Education was $44.78 \%$, and the Constraints for OHS with the sub-criteria for poor work culture in the field was $53.73 \%$.
\end{abstract}

Key words: Occupational Health, Occupational Safety, Analytical Hierarchy Process, Sanitary Landfill, Landfill.

\section{INTRODUCTION}

Cilegon is an autonomous city which was legally formed based on the constitution no. 15 of 1999 which is currently part of Banten Province. Astronomically, it is located between 0552 'North Latitude and 06 04' South Latitude and between 10554 ' 10605 'East Longitude and it is south of the equator. While geographically, it is located at the end of Java Island and it is the main gateway connecting Java Island and Sumatra Island ${ }^{1}$.

Based on a report by the Central Bureau of Statistics (BPS), "Cilegon in Figures of 2020" the area of Cilegon City of 175.51 Km, it is divided into 8 Districts and 43 Villages. In 2019 it has a total population of 437,205 people consisting of 223,002 men and 214,203 women with a population growth rate of 1.37 in 2018-2019 and a population density of 4,491 people ${ }^{1}$.

One of the causes of the population growth rate in this city is the high flow of urbanization. Along with the rate of population growth, it has resulted in an increasing the activities and interests of the people at the city. These activities include business activities, offices and household activities. The consequence of those activities is waste. The more activities carried out, the more waste is produced.

Sanitary Landfill is a waste management system that pays attention to environmental sanitation aspects. There is a process of spreading and compaction of waste in the landfill and closing the waste cells is carried out every day. The closure of the waste cells with a cover soil is also carried out everyday. This method is the standard method used international ${ }^{2}$. From the description above, it can be seen that the Sanitary Landfill system goes through the stages using a variety of heavy equipment operated by workers in the landfill to achieve the final result ${ }^{3}$. The operation of machines and tools by workers which is carried out regularly requires good stamina and concentration on every job or maintenance of a construction. All workers should be healthy on physic and mental, it means they should not only be healthy on physic, mental and social but also spiritually healthy. It is important to avoid accidents at work or becoming sick after work.

Therefore, this study will review and provide an assessment of the implementation of the OHS program in the landfills using the sanitary landfill system in Cilegon City. The success assessment and risk assessment are carried out at each stage of the activities in the landfill based on various points of view which are interpreted to the conclusion. 


\section{LITERATURE}

It is time for the waste to become a common problem with all components of the Cilegon City. Collaboration between people and the Regional Sanitation and Park Office of Cilegon is very important for waste management in the City. Society knowledge of the importance of a clean living by making it a habit to sort, recycle and take out the trash in its place properly is the first step in a successful waste management program.

\subsection{Operational Technical System}

The operational technicalities of waste processing / waste of city are determined by several things, among others

1. Patterns and operating systems that are used include: Sweeping, collecting, sorting, transporting and final disposal

2. The waste volume to the landfill and

3. Capacity of waste processing equipment

In general, waste management as follows:

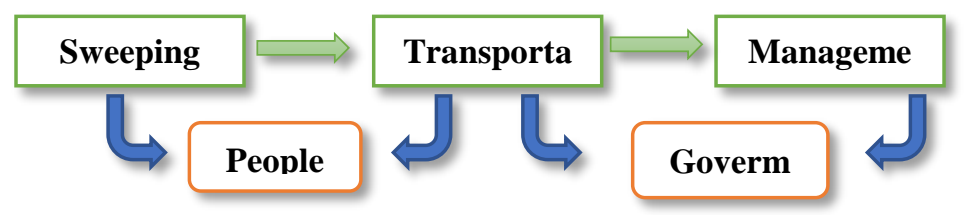

Figure 2.1 Waste management patterns (Directorate General of Human Settlements)

Patterns and standard specifications in the planning of waste management in Cilegon refer to the Indonesian National Standard (SNI) No. 3242-2008 5 about Waste Management Procedures in Settlements, (SNI) No. 3242-2008 ${ }^{5}$ concerning Procedures for City Waste Technical Management, SNI No. 19-3493-1995 ${ }^{9}$ about the specifications of waste production for small and medium cities in Indonesia. All these standards based on the constitution Number 18 of $2008^{6}$ concerning Waste Management and Number 32 of $2009^{4}$ concerning Protection and Enviromental Management. The waste management operational technical scheme as follows:

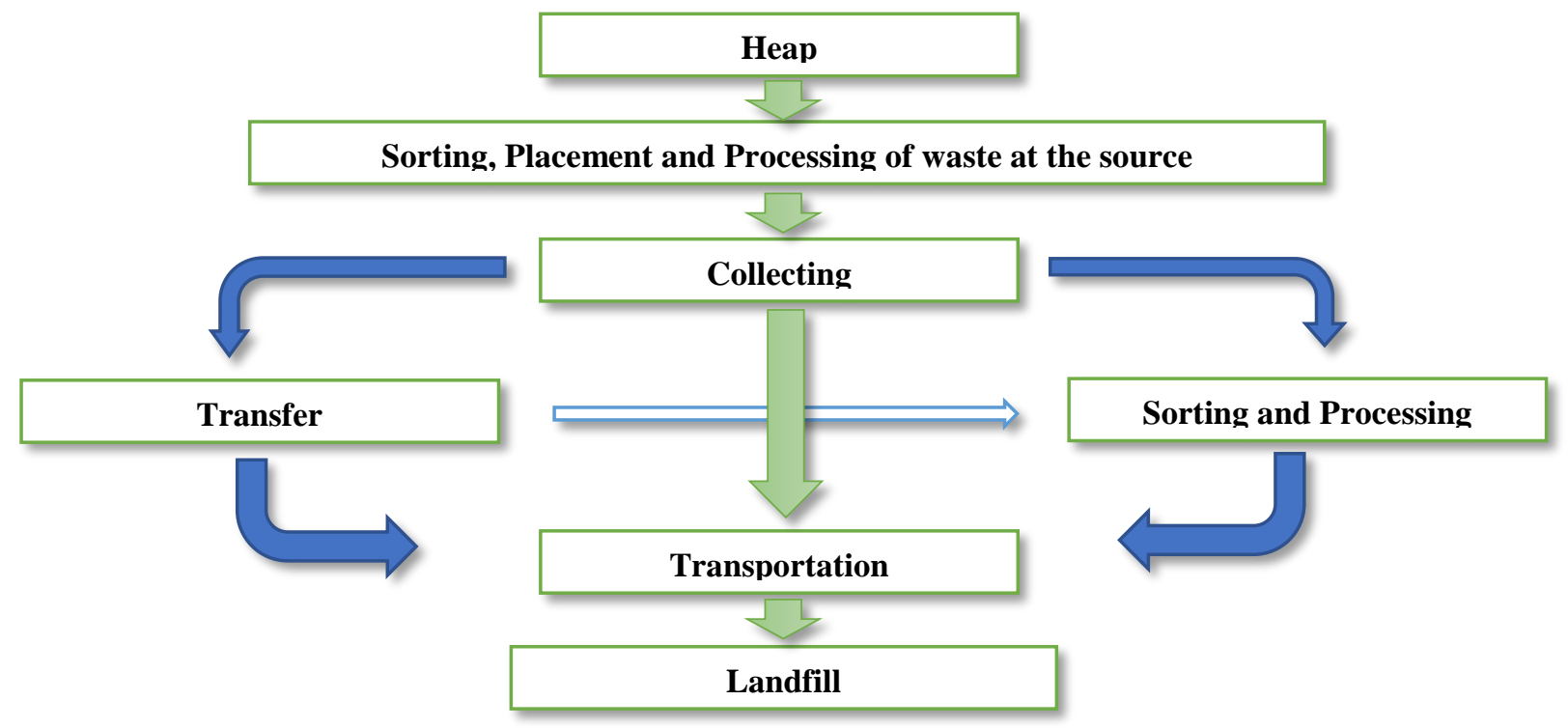

Fugure 2.2 Waste Management Operational Technical Diagram

Note :

1) Specific management of household waste refers to the regulations.

2) Sorting can also be carried out in collection and transfer activities

3) Sorting and recycling activities are prioritized at the waste source.

\subsection{Sanitary landfill Method}

According to Tchobanoglous et al $(1993)^{8}$, there are 3 methods commonly used in sanitary landfills, they are the trench method, the area method, the canyon method. 


\subsubsection{Trench Method}

Trench method is an ideal sanitary landfill method for areas that have an adequate supply of cover material and water that is far from the ground. Wastel is placed in cells that have been dug up. The soil is dug up every day and used as daily cover. Usually the cell excavation is rectangular with length and width of $305 \mathrm{~m}$, slope of 1.5: 1 to 2: 1. The excavation size can also be different, such as length $61 \mathrm{~m}-305 \mathrm{~m}$, depth $0.915 \mathrm{~m}-3.05 \mathrm{~m}$, and width $4.575 \mathrm{~m}-15.25 \mathrm{~m}$. The form of the trench method can be seen in Figure 2.4.

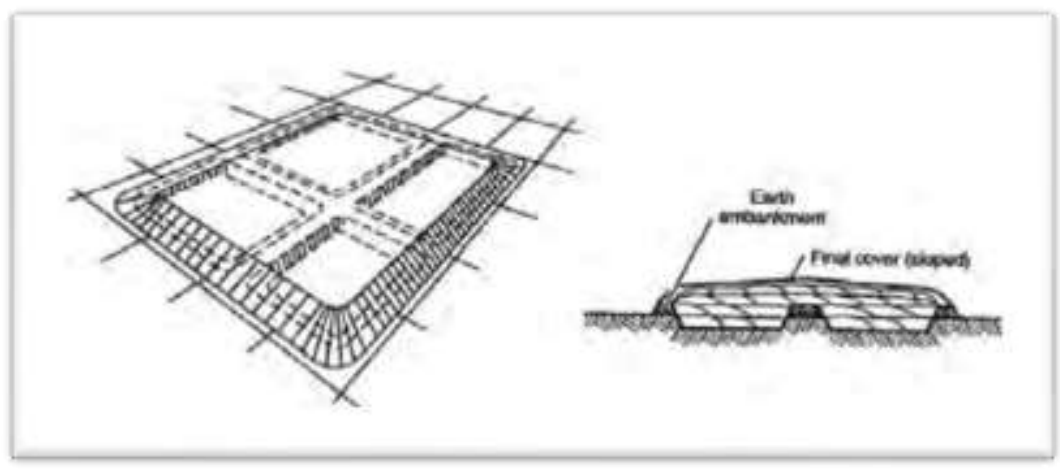

Figure 2.4 Trench $\operatorname{Method}^{8}$

\subsubsection{Area Method}

Area method is used when an area cannot be excavated because the high groundwater level as shown in Figure 2.5.

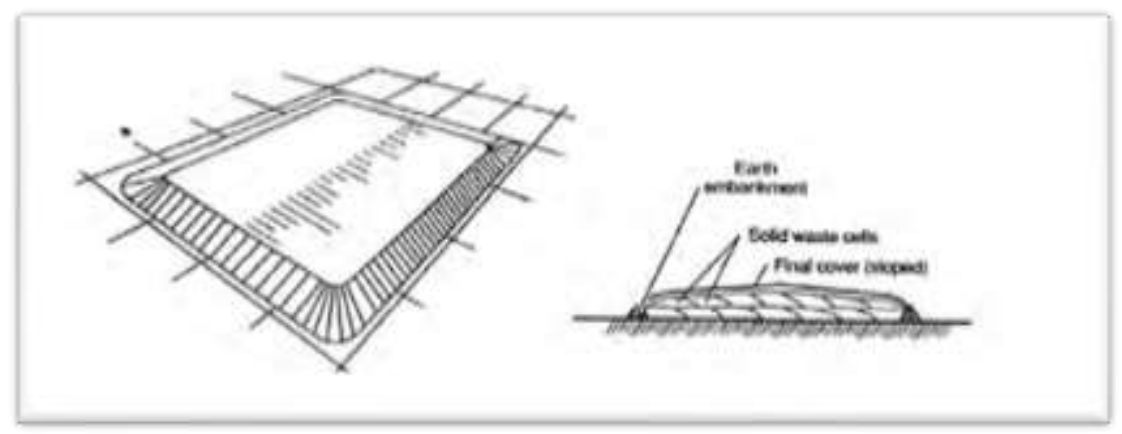

Figure 2.5 Area Method ${ }^{8}$

Place preparation also includes linear and leachate control installations. Cover soil in this method comes from the closest area that is transported by truck. If there is limited cover soil, composted waste can be used as cover soil.

\subsubsection{Canyon Method}

2.2.4.

Canyon method is a method using a ravine as a dump. The ravine part consists of many piles with an operational method similar to the area method. However, if the bottom of the ravine is flat, it can be excavated so that it's like a trench method. The advantage of this method is the daily cover soil for each pile is very much. It comes from the excavation of the wall or bottom of the ravine before the base coating system is installed. The canyon method form can be seen in Figure 2.6.

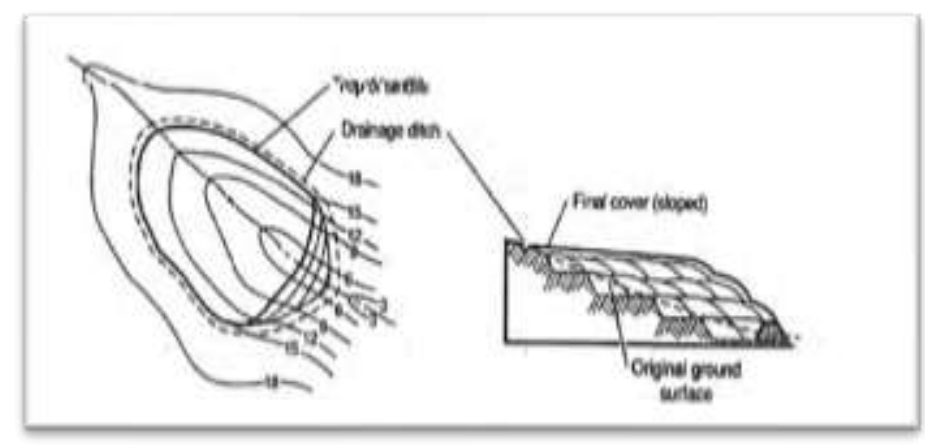

Figure 2.6 Canyon Method $^{7}$ 


\subsection{Analytic Hierarchy Process (AHP) Method}

The Analytical Hierarchy Process (AHP) method was originally developed by Thomas L. Saaty, a Mathematician from the Pittsburg University, United States of America in the early $1970^{8}$. AHP method is a tool to make choices from the difficult alternatives. This method works based on a combination of input various considerations from decision makers based on information about the support elements of decision, to determine a set of priority measurements in order to evaluate the various alternatives that will be taken in a decision.

\subsubsection{Preparation of Pairwise Matrix}

The process of mathematical calculations in the AHP method is carried out using a matrix. If in a sub operating system there are $\mathrm{n}$ operating criteria, they are A1, A2,..., An, then the results of the comparison of these operating elements will form a matrix A of nxn size with the form shown in Table

Table. Pairwise Comparison Matrix

\begin{tabular}{|c|c|c|c|c|}
\hline \hline Criteria & $\mathrm{A}_{1}$ & $\mathrm{~A}_{2}$ & $\ldots \ldots$ & $\mathrm{A}_{\mathrm{n}}$ \\
\hline \hline $\mathrm{A}_{1}$ & 1 & $\mathrm{~A}_{21}$ & $\ldots \ldots$ & $\mathrm{A}_{1 \mathrm{n}}$ \\
\hline $\mathrm{A}_{2}$ & $\mathrm{~A}_{12}$ & 1 & $\ldots \ldots$ & $\mathrm{A}_{2 \mathrm{n}}$ \\
\hline$\ldots \ldots$ & $\ldots \ldots \ldots$ & $\ldots \ldots$ & 1 & $\ldots \ldots$ \\
\hline $\mathrm{A}_{\mathrm{n}}$ & $\mathrm{A}_{1 \mathrm{n}}$ & $\mathrm{A}_{2 \mathrm{n}}$ & $\ldots \ldots$ & 1 \\
\hline
\end{tabular}

Source; Saaty, $1994^{8}$

Filling of $\mathrm{a}_{\mathrm{ij}}$ value using the following rules:

1. If $\mathrm{a}_{\mathrm{ij}}=\infty$ then $\mathrm{a}_{\mathrm{ij}}=0$

2. If the operating elements of Ai have the same importance, then the value of $a_{i j}=a_{i j}=1$

3. Value of $a_{i j}=1$ for $I=j$ the diagonal of the matrix has a value of 1

From the pairwise comparison matrix, partial weighting is carried out in the following steps:

1. Add up the values of each column in the pairwise comparison matrix.

2. Divide the $\mathrm{a}_{\mathrm{ij}}$ value in each column by the number of values in the column in order to get a normalized matrix.

3. Add up all the values of each row of the normalized matrix and divide it by the number of elements per row, which is the partial weight value.

4.

\subsubsection{Consistency Test}

Pairwise comparison of each element can be gotten through actual measurement as well as relative measurement of degree of liking, importance or feeling. In the pairwise comparison assessment, there is often inconsistency of the preferences given by the decision maker. In the AHP method, the consistency of the pairwise assessment is evaluated by calculating the Consistency Ratio (CR). If the CR value is smaller, equal to $10 \%$, then the results of the assessment can be said to be consistent. The model that is used to calculate $\mathrm{CR}$, it is shown in equation (1) below:

$\begin{array}{ll}C R=\frac{C I}{R I} \ldots \ldots \ldots \ldots \ldots \ldots \ldots \ldots \ldots \ldots \ldots \ldots \ldots \ldots \ldots \ldots \ldots \ldots \ldots \ldots \ldots \ldots \ldots \\ \text { Explanation: } & \\ C R & : \text { Consistency Ratio } \\ C I & : \text { Consistency Index } \\ R I & : \text { Random Consistency Index }\end{array}$

The value of the Consistency Index is shown in equation (2.2) below:

$\begin{array}{ll}C I=\frac{\kappa \max -1}{(n-1)} \ldots \ldots \ldots \ldots \ldots \ldots \ldots \ldots \ldots \ldots \ldots \ldots \ldots \ldots \ldots \ldots \ldots \ldots \ldots \ldots \ldots \ldots \ldots \\ \text { Explanation: } & \\ C I & : \text { Consistency Index } \\ \kappa \max & : \text { Maximum value of eigenvalue } \\ n & : \text { Matrix Size }\end{array}$


If the CI is zero, it can be said that the matrix is consistent. The inconsistency limit is measured using the random value (RI). Based on Saaty's calculations that using 500 samples, if the numerical considerations are taken randomly from a scale of 1/9, $1 / 8, \ldots, 1,2, \ldots, 9$ will be gotten the average value of consistency for a matrix of the different size, it is shown in the Table.

Tabel; Value of Random Index

\begin{tabular}{|c|c|c|c|c|c|c|c|c|c|c|}
\hline Matrix Order & 1 & 2 & 3 & 4 & 5 & 6 & 7 & 8 & 9 & 10 \\
\hline Random Index & 0,00 & 0,00 & 0,58 & 0,90 & 1,12 & 1,24 & 1,32 & 1,41 & 1,45 & 1,58 \\
\hline
\end{tabular}

AHP describes a structured approach to making decisions as a general choice among a number of alternatives that are considered to meet a series of objectives. Relative weights between criteria were obtained from pairwise comparison of the results of stakeholders' perceptions (stakeholders). So, AHP is a method for converting subjective estimates of relative importance into a set of scores or total weights.

The basic input for AHP is the decision maker's answers to a series of questions which in general terms, it can be expressed as "how important is criteria A relative to criteria B?" This condition talks a pairwise comparison. In the basic method developed by Saaty in 1994, it is used to identify the weight of a criteria based on a relatively advanced idea of matrix algebra and calculates the weight as an element of an eigenvector associated with the maximum eigenvector of a matrix. The estimation procedure is relatively complex with shorter alternatives, as follows:

1. Calculate the geometric average of each row in the matrix.

2. Add up all of the geometric average that is obtained in the first step.

3. Normalize each geometric average, it is divided by total of the geometric average which is calculated in the second step.

Relative weight between criterias and scores that is calculated by pairwise comparisons, then, decision making can be carried out with a linear additive model which is all alternatives have a weighted score.

\subsubsection{Weighting}

Making the weights between the criterias, it is necessary to get a survey of stakeholders who are involved and have an interest in the OHS Sanitary Landfill. After the survey, data was obtained to get a pairwise comparison matrix, it refers to the respondent's perception of each proposed planning criteria. The results were translated into a pairwise comparison matrix and then the weighting process was carried out.

The weight assessment or alternative scoring toward the criteria is generally carried out on a scale from 0 to 9 , it usually calls a numerical number and it represents the proportion of the importance level. This assessment tends to be more subjective but its quantitative character will be a description of the problem to be analyzed.

\section{METHODOLOGY RESEARCH OBJECTIVES}

\subsection{Research Objectives.}

The objectives of this research are:

1. Knowing the factors of OHS implementation and the OHS constraints in the landfill work that uses the landfill sanitray system.

2. Knowing the most in the implementation and the constraints in the landfill work that uses the landfill sanitray system.

\subsection{Methodology}

In this study, secondary data was collected to know the sub-variables and indicators that affect the implementation of OHS and the constraints of OHS. Secondary data collection was carried out based on literature studies. Furthermore, primary data was collected through a questionnaire survey to the experts who have the competence of occupational health and safety (OHS) related to landfills using the sanitary landfill system with at least 5 years of experience. . The following is a theoritical framework in this research. 


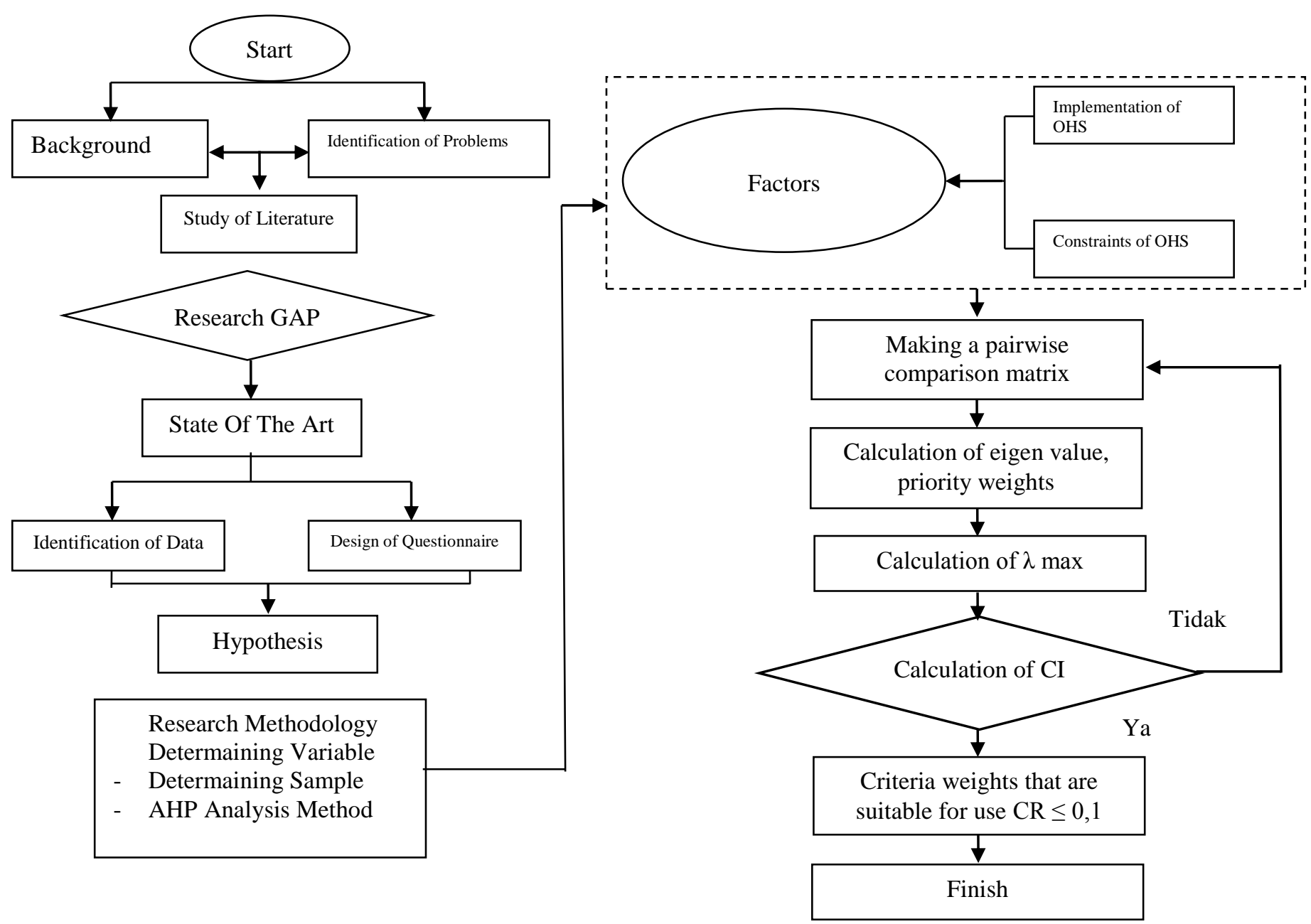

\section{THE RESULTS.}

Figure 2. Flow Research

AHP variables are arranged based on literature studies related to the stages of the implementation process or the constraints in the work safety management process in landfills using a sanitary landfill system which will then be assessed by the respondent and it will be processed with AHP. The following variables are shown in Table 4.1. :

Tabel. 4.1 Variables

\begin{tabular}{|c|c|c|}
\hline Criteria & Sub-Criteria & Alternative \\
\hline \multirow{9}{*}{ 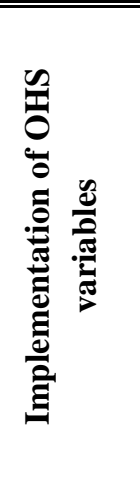 } & \multirow{3}{*}{ Prioritizing OHS } & $\begin{array}{ll}\text { a } & \text { Fulfillment of OHS laws and rules }\end{array}$ \\
\hline & & b Prioritizing OHS in implementation project \\
\hline & & c A routine OHS audit schedule \\
\hline & \multirow{3}{*}{$\begin{array}{c}\text { Education of } \\
\text { OHS }\end{array}$} & a Giving OHS socialization \\
\hline & & $\mathrm{b}$ Banners as a field education \\
\hline & & c Understanding of OHS procedures in the field \\
\hline & \multirow{3}{*}{$\begin{array}{l}\text { Involvement of } \\
\text { managers and } \\
\text { workers }\end{array}$} & a Parcitipated hazard identification \\
\hline & & b OHS training provision \\
\hline & & c Provision of adequate of Personal Protective Equipments (PPE) \\
\hline \multirow{8}{*}{ 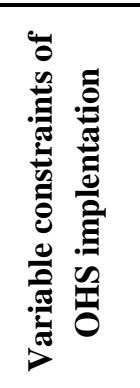 } & \multirow{3}{*}{$\begin{array}{l}\text { Poor work culture } \\
\text { in the field }\end{array}$} & a $\quad$ Lack of worker communication \\
\hline & & b Ignorance of OHS procedures \\
\hline & & c Openness to OHS supervisors \\
\hline & \multirow{3}{*}{$\begin{array}{l}\text { Punishment for } \\
\text { the person }\end{array}$} & a Invalid warning. \\
\hline & & b Invalid sanctions \\
\hline & & c $\quad$ Officers allow not to use PPE. \\
\hline & \multirow{2}{*}{ Weak supervisors } & a Absence of the OHS supervisors \\
\hline & & b Weak supervisors routinely \\
\hline
\end{tabular}




\begin{tabular}{|c|c|c|c|}
\hline \multirow{4}{*}{\begin{tabular}{c}
\multirow{4}{*}{$\begin{array}{c}\text { Workplace } \\
\text { factors }\end{array}$} \\
\cline { 2 - 3 }
\end{tabular}} & $\mathrm{c}$ & The equipment checklist does not apply \\
\hline & $\mathrm{b}$ & Feeling that you have prioritized OHS \\
\hline & $\mathrm{c}$ & Lack of motivation for OHS program \\
\hline & $\mathrm{d}$ & Feeling satisfied with the workplace \\
\hline
\end{tabular}

\subsection{Implementation of OHS}

OHS application is a self-protection effort to prevent occupational accidents and illnesses as a result of working and supervision in the workplace. OHS should be applied in all companies, especially those engaged in construction. That is because the risk of work accidents is bigger, it relates to many heavy equipment and multi-storey buildings. In the constitution no. 1 of 1970 it was written that the purpose of OHS was to prevent accidents and illnesses because of the work activities and using every source of production safely and efficiently. The following are the general functions and objectives of OHS that need to be applied in every construction work.

\section{1) Calculation of Eigen Value, Priority Weights and Totl of Pairwise Matrix}

Based on the results of the questionnaire presented of OHS's experts which related to landfills using the sanitary landfill system in the Cilegon city, it also related to the implementation of OHS and AHP processing that has been carried out, the results are shown in Table 4.2:

Table. 4.2 Results of Eigen Value, Priority Weights of OHS implementation

\begin{tabular}{|l|c|c|c|c|r|}
\hline & $\begin{array}{c}\text { Prioritizing } \\
\text { OHS }\end{array}$ & $\begin{array}{c}\text { Education } \\
\text { of OHS }\end{array}$ & $\begin{array}{c}\text { Involvement } \\
\text { of managers } \\
\text { and workers }\end{array}$ & $\begin{array}{c}\text { Eigen } \\
\text { Value }\end{array}$ & $\begin{array}{c}\text { Priority } \\
\text { Weights }\end{array}$ \\
\hline Prioritizing OHS & 1,0000 & 4,0000 & 3,0000 & 1,8612 & 0,5571 \\
\hline Education of OHS & 0,2500 & 1,0000 & 2,0000 & 0,8409 & 0,2517 \\
\hline $\begin{array}{l}\text { Involvement of managers and } \\
\text { workers }\end{array}$ & 0,3333 & 0,5000 & 1,0000 & 0,6389 & 0,1912 \\
\hline Total & $\mathbf{1 , 5 8 3 3}$ & $\mathbf{5 , 5 0 0 0}$ & $\mathbf{6 , 0 0 0 0}$ & $\mathbf{3 , 3 4 1 0}$ & $\mathbf{1 , 0 0 0 0}$ \\
\hline
\end{tabular}

Source : Researcher's processing.

2) Calculation of Distribution of each column, Synthetic Weights and Eigen Max (X).

The distribution of each column to get the synthetic weights and eigen weights is shown in Table 4.3

Table. 4.3 Results of Synthetic Weights and Eigen Max in the Implementation of OHS.

\begin{tabular}{|l|c|c|c|c|c|}
\hline & Prioritizing OHS & $\begin{array}{c}\text { Education } \\
\text { of OHS }\end{array}$ & $\begin{array}{c}\text { Involvement } \\
\text { of managers } \\
\text { and workers }\end{array}$ & $\begin{array}{c}\text { Synthetic } \\
\text { Weights }\end{array}$ & $\begin{array}{c}\text { Eign } \\
\text { Max } \\
(\mathbf{X})\end{array}$ \\
\hline Prioritizing OHS & 0,6316 & 0,7273 & 0,5000 & 1,8589 & 3,3368 \\
\hline Education of OHS & 0,1579 & 0,1818 & 0,3333 & 0,6730 & 2,6741 \\
\hline $\begin{array}{l}\text { Involvement of managers and } \\
\text { workers }\end{array}$ & 0,2105 & 0,0909 & 0,1667 & 0,4681 & 2,4477 \\
\hline Total & $\mathbf{1 , 0 0 0 0}$ & $\mathbf{1 , 0 0 0 0}$ & $\mathbf{1 , 0 0 0 0}$ & $\mathbf{3 , 0 0 0 0}$ & $\mathbf{8 , 4 5 9}$ \\
\hline
\end{tabular}

Source : Researcher's processing.

\subsection{The Constraints of OHS}

Even though OHS is important in the aspect of activities, in its implementation there are still the constraints, the following is the calculation of the dominant factors.

1. Calculation Eigen Value, Priority Weights and Totl of Pairwise Matrix

The constraints of OHS are presented in Table 4.4 
International Journal of Engineering Research And Advanced Technology, Vol.6( 9), September-2020

Table. 4.4 Results of Eigen Value, Priority Weights of the OHS constraints.

\begin{tabular}{|l|c|c|c|c|c|c|}
\hline & $\begin{array}{c}\text { Poor } \\
\text { work } \\
\text { culture in } \\
\text { the field }\end{array}$ & $\begin{array}{c}\text { Punishment } \\
\text { for the } \\
\text { person }\end{array}$ & $\begin{array}{c}\text { Weak } \\
\text { supervisors }\end{array}$ & $\begin{array}{c}\text { Workplace } \\
\text { factors }\end{array}$ & $\begin{array}{c}\text { Eigen } \\
\text { Value }\end{array}$ & $\begin{array}{c}\text { Priority } \\
\text { Weights }\end{array}$ \\
\hline Poor work culture in the field & 1 & 4 & 6 & 4 & 3,1302 & 0,5819 \\
\hline Punishment for the person & 0,2500 & 1 & 2 & 4 & 1,1892 & 0,2211 \\
\hline Weak supervisors & 0,1667 & 0,5000 & 1 & 2 & 0,6389 & 0,1188 \\
\hline Workplace factors & 0,2500 & 0,2500 & 0,5000 & 1 & 0,4204 & 0,0782 \\
\hline Total & $\mathbf{1 , 6 6 6 7}$ & $\mathbf{5 , 7 5 0 0}$ & $\mathbf{9 , 5 0 0 0}$ & $\mathbf{1 1 , 0 0 0 0}$ & $\mathbf{5 , 3 7 8 8}$ & $\mathbf{1 , 0 0 0 0}$ \\
\hline
\end{tabular}

Source : Researcher's processing.

2. Calculation of Distribution of each column, Synthetic Weights and Eigen Max (X).

From the comparison results in table 4.4 above, the results of Eigen Max for data validation are obtained, they are shown in table 4.5

Table. 4.5 Results of Synthetic Weights and Eigen Max in the OHS constraints.

\begin{tabular}{|l|c|c|c|c|c|c|}
\hline & $\begin{array}{c}\text { Poor } \\
\text { work } \\
\text { culture in } \\
\text { the field }\end{array}$ & $\begin{array}{c}\text { Punishment } \\
\text { for the } \\
\text { person }\end{array}$ & $\begin{array}{c}\text { Weak } \\
\text { supervisors }\end{array}$ & $\begin{array}{c}\text { Workplace } \\
\text { factors }\end{array}$ & $\begin{array}{c}\text { Synthetic } \\
\text { weights }\end{array}$ & $\begin{array}{c}\text { Eign } \\
\text { Maks (X) }\end{array}$ \\
\hline Poor work culture in the field & 0,6000 & 0,6957 & 0,6316 & 0,3636 & 2,2909 & 3,9365 \\
\hline Punishment for the person & 0,1500 & 0,1739 & 0,2105 & 0,3636 & 0,8981 & 4,0620 \\
\hline Weak supervisors & 0,1000 & 0,0870 & 0,1053 & 0,1818 & 0,4740 & 3,9906 \\
\hline Workplace factors & 0,1500 & 0,0435 & 0,0526 & 0,0909 & 0,3370 & 4,3115 \\
\hline Total & $\mathbf{1 , 0 0 0 0}$ & $\mathbf{1 , 0 0 0 0}$ & $\mathbf{1 , 0 0 0 0}$ & $\mathbf{1 , 0 0 0 0}$ & $\mathbf{4 , 0 0 0 0}$ & $\mathbf{1 6 , 3 0 0 5}$ \\
\hline
\end{tabular}

Source : Researcher's processing.

Based on the connection between the data taken from the questionnaire and validation to get the value of the Consistency Ratio, if the Consistency Ratio value $<0,1$ then the data is consistent. While based on the validation results, Consistency Ratio value for the implementation of OHS is $-0,1556<0,1$, it means the data is consistent. Futhermore, the Consistency Ratio fo the constraints of OHS is 0,0278 , it is still below 0,1 , it means that the data for OHS constraints are also be consistent.

Table. 4.6 Validation results of OHS Implementation and OHS Constraints.

\begin{tabular}{|c|c|c|c|c|c|c|c|c|c|}
\hline $\begin{array}{c}\text { CRITERI } \\
\mathrm{A}\end{array}$ & SUB-CRITERIA & $\begin{array}{l}\text { Eigen } \\
\text { Value }\end{array}$ & $\begin{array}{l}\text { Priority } \\
\text { Weights }\end{array}$ & $\begin{array}{l}\text { Synthet } \\
\text { ic } \\
\text { Weight } \\
\text { s }\end{array}$ & $\begin{array}{c}\text { Eign } \\
\operatorname{Max}(X)\end{array}$ & $\begin{array}{c}\lambda \max \\
(\text { lamda } \\
\max )\end{array}$ & $\begin{array}{c}\text { CI } \\
\text { (Consist } \\
\text { ency } \\
\text { Index })\end{array}$ & $\begin{array}{c}\text { CR } \\
\text { (Consist } \\
\text { ensy } \\
\text { Ratio) }\end{array}$ & $\begin{array}{c}\text { Explana } \\
\text { tion }\end{array}$ \\
\hline \multirow{3}{*}{$\begin{array}{l}\text { Implemen } \\
\text { tation of } \\
\text { OHS }\end{array}$} & Prioritizing OHS & 1,8612 & 0,5571 & 1,8589 & 3,3368 & \multirow[b]{3}{*}{2,8196} & \multirow[b]{3}{*}{$-0,0902$} & \multirow[b]{3}{*}{$-0,1556$} & \multirow{3}{*}{$\begin{array}{c}<0,1 \\
\text { consisten } \\
\text { cy }\end{array}$} \\
\hline & Education of OHS & 0,8409 & 0,2517 & 0,6730 & 2,6741 & & & & \\
\hline & $\begin{array}{l}\text { Involvement of } \\
\text { managers and } \\
\text { workers }\end{array}$ & 0,6389 & 0,1912 & 0,4681 & 2,4477 & & & & \\
\hline \multirow{4}{*}{$\begin{array}{l}\text { Constraint } \\
\mathrm{s} \text { of OHS }\end{array}$} & $\begin{array}{l}\text { Poor work culture } \\
\text { in the field }\end{array}$ & 3,1302 & 0,5819 & 2,2909 & 3,9365 & \multirow{4}{*}{4,0751} & \multirow{4}{*}{$\mathbf{0 , 0 2 5 0}$} & \multirow{4}{*}{$\mathbf{0 , 0 2 7 8}$} & \multirow{4}{*}{$\begin{array}{c}<0,1 \\
\text { consisten } \\
\quad \text { cy }\end{array}$} \\
\hline & $\begin{array}{l}\text { Punishment for the } \\
\text { person }\end{array}$ & 1,1892 & 0,2211 & 0,8981 & 4,0620 & & & & \\
\hline & Weak supervisors & 0,6389 & 0,1188 & 0,4740 & 3,9906 & & & & \\
\hline & Workplace factors & 0,4204 & 0,0782 & 0,3370 & 4,3115 & & & & \\
\hline
\end{tabular}

Source : Researcher's processing. 


\section{CONCLUSION}

Based on the research results, it can be concluded that there are 23 factors in the implementation and constraints of OHS management in landfills that use the sanitary landfill system in Cilegon City. In the OHS implementation criteria, there are 3 subcriteria (1) Prioritizing OHS of 55,71\%. (2) Education of OHS with a total percentage of $25,17 \%$ and (3) Involvement of managers and workers of 19,12\%. While the constraints of OHS, there are 4 sub-criteria used for the calculation using Analytic Hierarchy Process method, they are (1) Poor work culture in the field of 58,19\%, (2) Punishment for the person of 22,11\%. (3) Weak supervisors of $11,88 \%$ (4) Workplace factors of $7,82 \%$. Based on the data, the most dominant factor of implementation of OHS is prioritizing OHS, while for the constraints of OHS, poor work culture in the field is the dominant factor.

\section{REFERENCES}

[1] Badan Pusat Statistik / https://www.bps.go.id/ 03/03/2020

[2] Mayangkara (2016), Evaluation Of Waste Management Policy In Tpa Gunung Panggung, Tuban District, Hal 427- 444 e-ISSN: 2460-1586.

[3] Diharto (2009), Planning Study Of Tpa Buluminung In Panajam Paser Utara District With A Sanitary Landfill System, Hal 191-200.

[4] Undang-Undang Republik Indonesia (2009), Protection And Management Of The Environment, Nomor 32 Hal 1110.

[5] Indonesian National Standard (2008), Waste Processing In Settlements, SNI 3242:2008 Hal 1-23.

[6] Undang-Undang Republik Indonesia (2008), Waste Processing, Nomor 18 Hal 1-46.

[7] Saaty,T.L. (1994). How to Make a Decision: The Analytic Hierarchy Process. Interfaces,24,19-43. https://doi.org/10.1287/inte.24.6.19.

[8] Tchobanoglous, G., et al. (1993). Integrated Solid Waste Management. McGraw Hill. New York.

[9] Undang-Undang Republik Indonesia (1970), work safety, Nomor 1 Hal 1-15. 